\title{
Association of the Level of Knowledge Regarding Effects of Alcoholism with Selected Demographic Variables of Rural Adults
}

Sah I*

*Lecturer, College of Nursing Sciences, Gandaki Medical College, Pokhara, Nepal

\begin{abstract}
Background: Alcoholism is the most severe form of alcohol abuse and involves the inability to manage drinking habits. It is also commonly referred to as alcohol use disorder. Alcohol use disorder is organized into three categories: mild, moderate and severe. Each category has various symptoms and can cause harmful side effects. If left untreated, any type of alcohol abuse can spiral out of control.
\end{abstract}

Objectives: To assess the demographic variables of rural adults, to associate the level of knowledge regarding effects of alcoholism with selected demographic variables of rural adults.

Methods: A Quasi experimental one group pre-test post-test research design was used. The structured interview schedule was developed to collect data. The study was conducted at Challaghatta Village, Bangalore, Karnataka, India and the data collected was analyzed and interpreted based on descriptive and inferential statistics.

\section{Keywords}

Alcohol dependence, Effectiveness,

Knowledge.

\section{Corresponding author}

*Ms Indu Sah

M.Sc Nursing, Lecturer

College of Nursing Sciences,

Gandaki Medical College,

Pokhara, Nepal

Email:indukali58@gmail.com
Results: The associated pre-test level of knowledge regarding the effects of alcoholism among rural adults with their demographic variables in the study is non significant with the demographic variables at $p>0.05$ level.

Conclusion: The present study found that there is no significant association between the demographic variables and level of knowledge among rural adults regarding effects of alcoholism.

\section{INTRODUCTION}

Alcoholism, also known as alcohol use disorder (AUD), is a broad term for any drinking of alcohol that results in mental or physical health problems ${ }^{2}$. The disorder was previously divided into two types: Alcohol abuse and alcohol dependence ${ }^{3}$. In a medical context, alcoholism is said to exist when two or more of the following conditions are present: A person drinks large amounts over a long time period, has difficulty cutting down, acquiring and drinking alcohol takes up a great deal of time, alcohol is strongly desired, usage results in not fulfilling responsibilities, usage results in social problems, usage results in health problems, usage results in risky situations, withdrawal occurs when stopping, and alcohol tolerance has occurred with use ${ }^{1}$.

Alcohol use disorders refer to excessive drinking behaviors that can create dangerous conditions for an individual and others. Alcohol abuse is a pattern of drinking that result in adverse outcomes such as:

- Failure to fulfill work or personal obligations

- Recurrent use of alcohol in potentially dangeros situations

- Problems with the law

- Continued use in spite of harm being done to social or personal relationships 
Alcohol dependence (AD) is the medical term for alcoholism. AD is characterized by:

- Increased amounts of alcohol are needed to produce an effect (tolerance)

- Withdrawal symptom (nausea, sweating, irritability, tremors, hallucinations, and seizures) develop when drinking is stopped or reduced

- Constant craving for alcohol and inability to limit drinking

- Continuing to drink in spite of the knowledge of its physical or psychological harm to oneself or others ${ }^{4}$.

\section{METHODS}

Quantitative research approach was selected as the methodology for the study. The setting of the study was in Sullikere, a rural area in Bangalore District of Karnataka State, India. Probability random sampling method was used for sample selection ${ }^{5}$. A sample size of 20 adults was taken for the study based on inclusive criteria. The tool used for the study was partner interview questioner which includes questionnaire in alcoholism, such as meaning, clinical manifestation, causes, effects, complication, management, rehabilitation. To assess the level of knowledge, 25 multiple choice questions were formed each one given the score of 0,1 respectively according to their response. Three structured interview among the subjects was conducted on a one to one basis in their homes.

\section{Variables}

1. Study variables: The level of knowledge regarding effects of alcoholism among rural adults.

2. Demographic variables: Demographic variables of adults aged between 20 - 50 years, sex, religion, educational status, occupation and monthly Income.

\section{Plan for data analysis}

Data collected was analyzed by using descriptive and inferential statistics.

\section{Descriptive statistics}

Frequency distribution was used to describe the demographic variables

\section{Inferential statistics}

Chi-square test was used to associate the level of knowledge regarding the effects of alcoholism among adults (20-50 years) with their demographic variables.

\section{RESULTS}

\section{Organization and Presentation of data}

Section 1: Assess the demographic variables of rural adults.

Section 2: Associate between pretest knowledge on effects of alcoholism among adults with their selected demographic variables.

\section{Presentation of Data}

Section 1: Frequency and percentage distribution of the demographic variables of rural adults.

Table 1: Assessment of demographic variables in frequency and percentage $(n=20)$

\begin{tabular}{|c|c|c|c|}
\hline Sl. No & Demographic Value & No & Percentage (\%) \\
\hline \multirow[t]{5}{*}{1.} & Age in years & & \\
\hline & a. $20-30$ & 10 & 50 \\
\hline & b. $31-40$ & 9 & 45 \\
\hline & c. $41-50$ & 1 & 5 \\
\hline & d. $20-50$ & 0 & 0 \\
\hline \multirow[t]{3}{*}{2.} & Sex & & \\
\hline & a. Males & 20 & 100 \\
\hline & b. Females & 0 & 0 \\
\hline \multirow[t]{3}{*}{3.} & Marital status & & \\
\hline & a. Married & 12 & 60 \\
\hline & b. Unmarried & 8 & 40 \\
\hline \multirow[t]{5}{*}{4.} & Education status & & \\
\hline & a. No Formal Education & 1 & 5 \\
\hline & b. Primary & 5 & 25 \\
\hline & c. High School & 9 & 45 \\
\hline & d. Bachelors & 5 & 25 \\
\hline \multirow[t]{3}{*}{5.} & Occupation & & \\
\hline & a. Working & 8 & 40 \\
\hline & b. Not working & 12 & 60 \\
\hline \multirow[t]{5}{*}{6.} & Monthly income in Rs. (INR) / Month & & \\
\hline & a. Income & 0 & 0 \\
\hline & b. Below 3000 & 1 & 5 \\
\hline & c. $3000-5000$ & 5 & 25 \\
\hline & d. Above 5000 & 14 & 70 \\
\hline \multirow[t]{3}{*}{7.} & Type of family & & \\
\hline & a. Nuclear family & 3 & 15 \\
\hline & b. Joint family & 17 & 85 \\
\hline \multirow[t]{3}{*}{8.} & Habits of drinking alcohol & & \\
\hline & a. Yes & 7 & 35 \\
\hline & b. No & 13 & 65 \\
\hline
\end{tabular}

Section 2: Association between pre-test knowledge regarding effects of alcoholism with their selected demographic variables. 
Table 2: Association of the pre-test knowledge with their selected demographic variables $n=20$

\begin{tabular}{|c|c|c|c|c|c|c|c|c|c|}
\hline \multirow[t]{2}{*}{ S.N } & \multirow[t]{2}{*}{ Demographic Value } & \multirow[t]{2}{*}{ No } & \multicolumn{2}{|c|}{ Inadequate } & \multicolumn{2}{|c|}{ Moderate } & \multicolumn{2}{|c|}{ Adequate } & \multirow[t]{2}{*}{ Chis square ralue } \\
\hline & & & $\mathrm{F}$ & $\%$ & $\mathrm{~F}$ & $\%$ & $\mathrm{~F}$ & $\%$ & \\
\hline \multirow[t]{5}{*}{1} & Age ( In years) & & & & & & & & \\
\hline & a. $20-30$ & 10 & 7 & 35 & 3 & 15 & 0 & 0 & \\
\hline & b. $\quad 31-40$ & 9 & 8 & 40 & 1 & 5 & 0 & 0 & 1.305 \\
\hline & c. $41-50$ & 1 & 1 & 5 & 0 & 0 & 0 & 0 & df 6 \\
\hline & d. $\quad 20-50$ & 0 & 0 & 0 & 0 & 0 & 0 & 0 & N.S \\
\hline \multirow[t]{3}{*}{2} & Sex & & & & & & & & \\
\hline & a. Males & 17 & 16 & 80 & 4 & 20 & 0 & 0 & 0 \\
\hline & b. Females & 3 & 0 & 0 & 0 & 0 & 0 & 0 & df2 N.S \\
\hline \multirow[t]{3}{*}{3} & Marital Status & & & & & & & & \\
\hline & a. Married & 12 & 9 & 45 & 3 & 15 & 0 & 0 & 0.4625 \\
\hline & b. Unmarried & 8 & 7 & 35 & 1 & 5 & 0 & 0 & $\mathrm{df} 2$ \\
\hline \multirow[t]{5}{*}{4} & Educational Status & & & & & & & & N.S \\
\hline & $\begin{array}{l}\text { a. No formal } \\
\text { education }\end{array}$ & 1 & 1 & 5 & 0 & 0 & 0 & 0 & \\
\hline & b. Primary & 5 & 2 & 10 & 1 & 5 & 0 & 0 & 1.456 \\
\hline & c. High school & 9 & 8 & 40 & 1 & 5 & 0 & 0 & df 6 \\
\hline & d. Bachelors & 5 & 5 & 25 & 2 & 10 & 0 & 0 & N.S \\
\hline \multirow[t]{3}{*}{5} & Occupation & & & & & & & & \\
\hline & a. Working & 8 & 5 & 25 & 3 & 15 & 0 & 0 & 2.545 \\
\hline & b. Not working & 12 & 11 & 55 & 1 & 5 & 0 & 0 & df 2 N.S \\
\hline \multirow[t]{5}{*}{6} & Monthly Income & & & & & & & & \\
\hline & a. Income & 0 & 0 & 0 & 0 & 0 & 0 & 0 & \\
\hline & b. Below 3000 & 1 & 1 & 5 & 0 & 0 & 0 & 0 & 1.777 \\
\hline & c. $3000-5000$ & 5 & 3 & 15 & 2 & 10 & 0 & 0 & df 6 \\
\hline & d. Above 5000 & 14 & 12 & 60 & 2 & 10 & 0 & 0 & N.S \\
\hline \multirow[t]{3}{*}{7} & $\begin{array}{l}\text { Types of } \\
\text { family }\end{array}$ & & & & & & & & \\
\hline & a. Nuclear family & 3 & 2 & 10 & 1 & 5 & 0 & 0 & 0.801 \\
\hline & b. Joint family & 17 & 14 & 70 & 3 & 15 & 0 & 0 & df 2 N.S \\
\hline \multirow[t]{4}{*}{8} & $\begin{array}{l}\text { Do you have } \\
\text { habits of drinking }\end{array}$ & & & & & & & & \\
\hline & a. Yes & 8 & 6 & 30 & 2 & 10 & 0 & 0 & 0.631 \\
\hline & b. No & 12 & 10 & 50 & 2 & 10 & 0 & 0 & df 2 N.S \\
\hline & & J.S - 1 & ot sig & ifican & . & $\%$ le & & & \\
\hline
\end{tabular}

The above Table 2 shows the associated pre-test level of knowledge regarding the effects of alcoholism among rural adults with their demographic variables in the study is non-significant with the demographic variables.

\section{DISCUSSION}

Present study aims to associate the level of knowledge regarding effects of alcoholism with selected demographic variables of rural adults. The discussion of the study is based on the statistical analysis of the study ${ }^{6}$.

The demographic variables of the present study reveals that regarding age distribution of adults majority 10 (50\%) of them belongs to 20 - 30 years. Regarding sex 20 (100\%) of them are males and none of them belongs to females. Regarding the distribution of marital status majority 12 (60\%) of them are married. Regarding the educational status majority 9 (45\%) of them belongs to high school education. Regarding occupational status, majority 12 (60\%) of them belongs to non working group. According to family income a large proportion of $14(70 \%)$ of adults belong to the family income of above Rs 5000 (INR). Regarding the type of family, a majority 17 (85\%) of them were from joint family. Regarding the habit of drinking alcohol majority 13 (65\%) belongs to the drinking group.

A similar descriptive study was conducted on knowledge towards alcoholism among 200 P.U. (Pre-University) College students of age 12 - 16 years in Mangalore Taluk, Karnataka State, India selected by random sampling technique. The findings of the study revealed that majority of students 83 (41.5\%) had favorable attitude toward alcoholism ${ }^{7}$.

A similar study was conducted on substance abuse among 489 adolescents in urban slums of Sambalpur, Orissa by simple random sampling technique from 29 municipality ward. The study revealed that $14.7 \%$ of adolescents were using alcohol and the median age of substance abuse for males was 15.09 years old and 15.29 for females. The study recommended a very pragmatic approach to the problem by improving education and communication activities directed towards adolescents and their family members ${ }^{8}$.

There is no significant association between the levels of knowledge regarding effects of alcoholism among demographic variables. The results show that there is no significant association between the level of knowledge regarding effects of alcoholism among demographic variables.

This study is also supported by a descriptive study which was conducted on approaches to alcohol addiction which examined the available scientific literature to provide an overview of different approaches that are being integrated increasingly to advance their knowledge of the genetic based alcoholism. Genetic factors account for more than $50 \%$ of the variance in alcoholism liability ${ }^{9}$. 


\section{CONCLUSION}

The study was conducted to associate the level of knowledge regarding effects of alcoholism with selected demographic variables of rural adults, the results have shown that there is no significant association between the level of knowledge regarding effects of alcoholism which also emphasizes that irrespective of any demographic status, adults should be given health teaching about ill effects of alcoholism.

\section{REFERENCES}

1. "Alcohol Use Disorder: A Comparison between DSM-IV and DSM-5". November 2013.

2. Littrell J. Understanding and Treating Alcoholism Volume I: An Empirically Based Clinician's Handbook for the Treatment of Alcoholism: Volume I: Biological, Psychological, and Social Aspects of Alcohol Consumption and Abuse. Hoboken: Taylor and Francis. 2014; page no; 55.

3. Hasin, Deborah. Classification of Alcohol Use Disorders. December 2003.
4. Pompili M, Serafini G, Innamorati M, Dominici G, Ferracuti S, Kotzalidis G, Sher L. Suicidal behavior and alcohol abuse. International Journal of Environmental Research and Public Health. 2010 April; 7(4): 1392-1431.

5. Basavanthappa BT. Nursing research. New Delhi. Jaypee publications. 1998; First edition. Page no: 262-268.

6. Makhija N. Introduction to Research Process. Nightingale Nursing Times. 2006 May; Page no: 18-20.

7. Kumar, Ravindra KV. A study to assess the knowledge towards the effect of alcohol among the students in a selected Pre-university college in Bangalore. http://119.82.96.198:8080/jspui/ handle/123456789/1510.

8. Sarangi L, Acharya PH. Substance abuse among adolescents in Urban slums of Samabalpur. Indian Journal Community. Oct 2008; 33(4): 265-7.

9. Ducci F, Goldman D. Genetic approaches to addiction. Addiction. 2001 September; 103(9): 1414-1428. 